\title{
APC mutation and phenotypic spectrum of Singapore familial adenomatous polyposis patients
}

\author{
Xia Cao ${ }^{1}$, Kong Weng Eu ${ }^{1}$, Francis Seow-Choen ${ }^{1}, Y_{i} Z o^{2}$ and Peh Yean Cheah ${ }^{1}$ \\ ${ }^{1}$ Department of Colorectal Surgery, Singapore General Hospital; ${ }^{2}$ Department of Clinical Research, Singapore General \\ Hospital, Singapore, Republic of Singapore
}

Familial adenomatous polyposis (FAP) is a familial form of colon cancer caused by mutation of the adenomatous polyposis coli (APC) gene. Although the APC gene has been extensively studied in the Caucasian population, it has not been previously described in the Chinese population. In the present study, we investigated APC mutation and phenotypic spectrum in the Singapore FAP families who are predominantly Chinese. The protein truncation test (PTT) was used to screen the entire APC gene for germline mutations in $\mathbf{2 8}$ unrelated families. Fifteen different mutations were identified in 22 families. Eight mutations were 1-11 basepair deletions or insertions; three involved deletions of whole exons and four were nonsense mutations. Nine of the mutations, including two complex rearrangements, are novel. Eight families including three de novo cases have the same (AAAGA) deletion at codon 1309, indicating that like the Western families, codon 1309 is also the mutation 'hot spot' for Singapore FAP families. In contrast, we did not find any mutation in codon 1061, the second hot spot for the Western population. Congenital hypertrophy of the retinal pigment epithelium (CHRPE) is consistently associated with the prescribed domain (codons 463 to 1387 ) and is the only phenotype with no intra-family variation. Other than CHRPE, differences in the type and frequency of extracolonic manifestations within the FAP families suggest the influence of modifying genes and environmental factors. European Journal of Human Genetics (2000) 8, 42-48.

Keywords: APC germline mutation; PTT; genotype-phenotype correlation; FAP

\section{Introduction}

Familial adenomatous polyposis (FAP), an autosomal dominantly inherited form of colon cancer is characterised by the appearance of hundreds to thousands of adenomatous polyps in the colon and rectum of an affected individual by the second or third decade of his life. The risk of cancer is virtually $100 \%$ if the polyps are not detected and removed in time. FAP patients often devel op extracolonic manifestations such as osteomas, desmoids, retinal lesions, brain and thyroid tumors. ${ }^{1}$

The Adenomatous polyposis coli (APC) gene on the long arm of chromosome 5 has been implicated in the pathogenesis of FAP. ${ }^{2-4}$ The APC gene spans well over 100 kilobases of genomic region. It contains 16 exons, one non-coding and 15 coding exons. The coding sequence is 8.5 kilobases long and codes for a large protein that is 2843 amino acid residues.

Correspondence: Peh Yeah Cheah, Department of Colorectal Surgery, Singapore General Hospital, Singapore 169608. Tel: +653213636; Fax: +65 2262009; E-mail: gcscpy@sgh.gov.sg

Received 17 May 1999; revised 27 July 1999; accepted 6 August 1999
More than $98 \%$ of the reported APC mutations are translation terminating mutations resulting in truncated proteins. $^{5}$

The severity and extracolonic manifestations of FAP appear to be correlated with the site of the mutation. Mutations between codons 1250 and 1464 of APC are associated with increased number of polyps. ${ }^{6}$ Mutation in the very $5^{\prime}$ and $3^{\prime}$ ends of the protein as well as the alternatively spliced sites in exon 9 have been associated with a more attenuated form of FAP. $^{7-9}$ Truncating mutations between codons 463 and 1387 are associated with congenital hypertrophy of the retinal pigment epithelium (CHRPE), ${ }^{10}$ whilst truncating mutations between codons 1403 and 1578 are associated with Gardner's syndrome ${ }^{11}$ such as increased desmoids and mandibular lesions but not CHRPE.

Genetic test for FAP screening became more feasible with the development of the protein truncation test ${ }^{12,13}$ which combines polymerase chain reaction (PCR) and in vitro transcription and translation techniques to detect translation terminating mutations. Unlike linkage study, no family 
history is required to carry out the test. In this study, we used the PTT to screen 28 unrelated FAP families (20 Chinese, five Malay, and three others) from the Singapore Polyposis Registry to determine the mutational profile in relation to the phenotypic spectrum of the local population, which is predominantly Chinese.

\section{Materials and methods \\ Sample selection}

Blood was collected over the past 8 years from 115 members of 28 unrelated FAP families. Pedigrees for these families were retrieved from the Singapore Polyposis Registry in the Department of Colorectal Surgery, Singapore General Hospital. Patient sample collection and screening were performed according to guidelines of the Ethics Committee of Singapore General Hospital.

\section{DNA/RNA extraction}

DNA was obtained from peripheral blood lymphocytes by a simple salting out procedure. ${ }^{14}$ RNA extraction was performed from fresh blood lysates using the Promega (Madison, WI, USA) Total RNA extraction kit according to the manufacturer's protocol.

\section{PTT assay}

The APC coding region of the human gene (Genebank accession number M 73548) was amplified by six overlapping PCR/RT-PCR segments corresponding to nucleotides 1-1800 (Segment 1.1); 1041-2514 (Segment 1.2); 2056-3831 (Segment 2); 3297-5410 (Segment 3); 4783-7011 (Segment 4) and 6364-8543 (Segment 5) as previously described. ${ }^{15}$ The un purified PCR product was in vitro transcribed and translated into protein with the TNT/T7 coupled reticulocyte lysate system (Promega, Madison, WI, USA).

\section{Sequence analysis}

The size of the truncated protein was used to estimate where the mutation was. The relevant PCR fragment was identified and primers made for PCR-based sequencing using PerkinElmer (Norwalk, CT, USA) automated $A B I^{T M}$ sequencer.

\section{Restriction enzyme digest}

The mutation in FAP family 5 (Segment 1 ) is a substitution of an adenine by guanine at position -6 from the splice acceptor site in intron 10, resulting in the loss of the Dra I enzyme site (TTTAAA). Restriction enzyme digest was used to confirm the mutation on other members of FAP 5 where only DNA was available.

\section{Results and discussions APC germline mutations}

We used the PTT to screen the entire coding region of the APC gene for germline mutation in 28 unrelated FAP families and found mutation in 22 families. Eight mutations were found in Segment1, three in Segment 2 and eleven in Segment3. Figure 1A shows a representative PTT gel for segments 1 to 3 . No mutation was found in segments 4 and 5 . This is not surprising as the literature shows that most APC mutations occur in the $5^{\prime}$ half of the APC gene. ${ }^{16,17}$ In order not to miss truncating mutations at the very ends of the APC coding region, we sequenced the $5^{\prime}$ and $3^{\prime}$ ends (covering the first 400 and last 300 nucleotides respectively) of the PCR fragments for the six families without PTT detectable mutations. No further mutation was found.

The detailed analysis of 72 members from these 22 FAP families whose blood samples were available for PTT analysis shows that the mutated APC gene was found in all 43FAP patients. In fact, truncated proteins were found in two young at-risk individuals (FAP 14 III7, 34 III1 in Table1) and subsequent colonoscopy confirmed the presence of polyps. None of the 24 individuals clinically diagnosed as unaffected members have the truncated protein. There is thus a $100 \%$ correlation between clinical diagnosis by colonoscopy and molecular diagnosis by PTT. Five at-risk individuals who tested positive for PTT were advised to undergo regular colonscopy.

Sequencing analysis of the PCR fragments giving rise to truncation confirm the mutation at nucleotide level in all 22 families. Fifteen different mutations were found (Table 1 ). Despite 300 known germline mutations in APC to date, $60 \%$ of the mutations (9 out of 15) from this study are novel. These mutations at codon positions470, 581, 674, 831, 938, 1343, 1428 and 1503 have not been previously reported in the Human Gene Mutation database. The 'codon' nomenclature used is as per the APC mutation data base (http:/ /perso.curie.fr/Thierry.Soussi/).

Frameshift mutations Eight different frameshift mutations caused by the deletion or insertion of small number of nucleotides were identified in 15 unrelated families (Table 1 ). Only two mutations at positions 299 and 1309 have been previously described. In the novel mutation at position 470, genomic DNA and cDNA sequencing analyses reveal that the base adenine at position -6 from the splice acceptor site of exon 11 is substituted with guanine. This substitution created a new splice acceptor site at this position and the insertion of 5 base pair (attag) before the original site (tttaaattag/GGG $\rightarrow$ tttag/attagGGG) resulting in a shift in frame and premature termination at codon 470 . This mutation is the first instance of a mutation at this position (-6) of an intron for the APC gene. In the novel mutation at position 674, a 5 base pair direct repeat (ATAGT) is located before the 11 base pairs deleted (ATAGTttgacaatagtCAG). This feature could possibly be important for the mechanism causing the deletion. In another novel mutation at position 831 , an adenine residue is inserted at codon position 831, resulting in a frameshift and translation termination at codon 843 (Figure $1 \mathrm{~B}$, right panel). The other three novel mutations $(938,1343,1428)$ are all small deletions, involving one to four base pairs in exon 15 (Table1). 
A

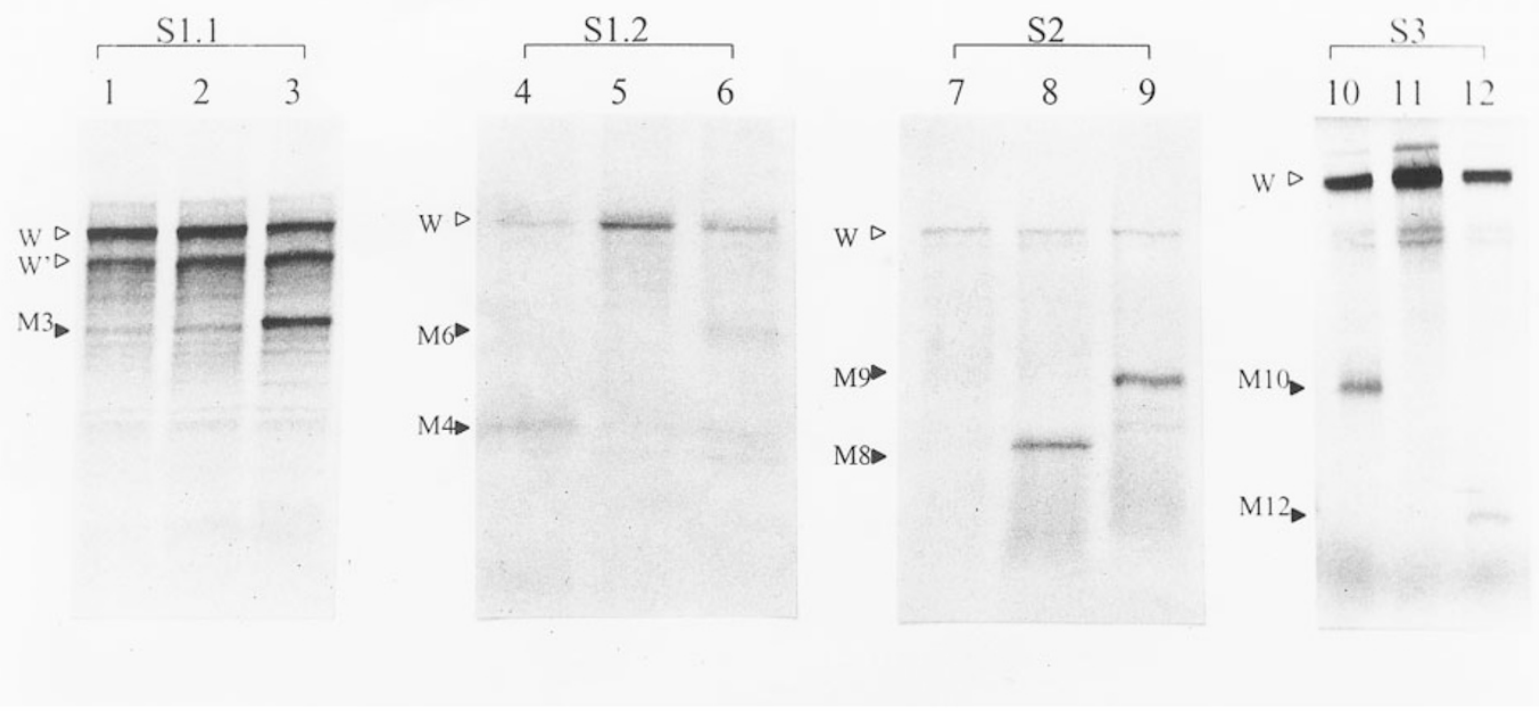

B
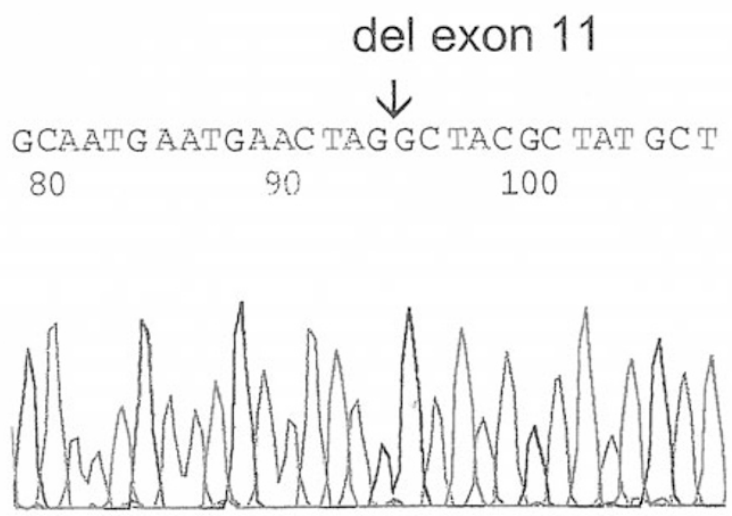
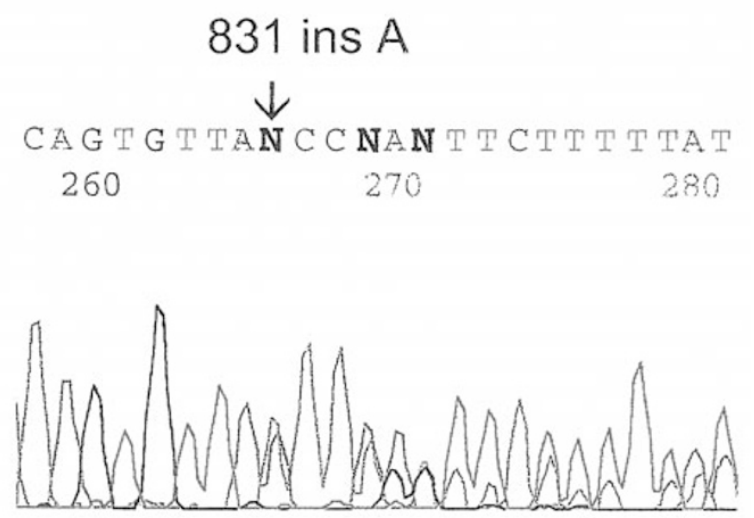

Figure 1 A Representative PTT analysis for APC segment 1.1 (lanes 1-3), segment 1.2 (lanes 4-6), segment 2 (lanes 7-9) and segment 3 (lanes 10-12). Each lane represents the PTT result of a different family. The full length protein (WT) is found in all lanes. An additional full length product ( $\left.W^{\prime}\right)$ due to alternative splicing is seen in segment 1.1. M3, M4, M6, M8, M9, M10 and M12 are truncated proteins found in lanes 3, 4, 6, 8, 9, 10 and 12 respectively. B Sequencing analysis for novel mutations at positions 470 (left panel) and 831 (right panel). In 470, the lower band from cDNA amplification was purified and sequenced. The sequence reads through from exon 10 (to the left of the arrow) to exon 12 (to the right of the arrow) indicating that exon 11 is missing. In 831 , the base adenine is inserted at nucleotide position 2493 (arrow) resulting in termination at codon 843.

Deletion of whole exons Three different mutations resulting in the deletion of exons 11 and 14 were identified in three families (Table1). Two out of three of these mutations are novel. In FAP family 4, truncated proteins were found in five patients. DNA sequencing on two individuals (III:8 and III:12 in Table1) reveal a deletion of exon 11 in the cDNA (Figure1B, left panel). However, no mutation at either the splice acceptor or donor site of exon 11 or the neighbouring 
Table 1 APC germline mutations and phenotypic spectrum

\begin{tabular}{|c|c|c|c|c|c|c|c|c|c|}
\hline Exon & Position & Mutation & $\begin{array}{l}\text { FAP } \\
\text { patient }\end{array}$ & $\begin{array}{l}\text { APC } \\
\text { mutation }\end{array}$ & $\begin{array}{l}\text { Age at } \\
\text { diagnosis }\end{array}$ & $\begin{array}{l}\text { Colonic } \\
\text { polyps* }\end{array}$ & $\begin{array}{l}\text { nanifestations } \\
\text { cancer** }\end{array}$ & $\begin{array}{l}\text { Extracolo } \\
\text { CHRPE }^{@}\end{array}$ & $\begin{array}{l}\text { c manifestation } \\
\text { Others }\end{array}$ \\
\hline 6 & 232 & CGA-IGA & $\begin{array}{l}9 \text { I:1 } \\
9 \text { II:1 } \\
9 \text { II:2 } \\
9 \text { II: } 3\end{array}$ & $\begin{array}{l}\text { N.D. } \\
+ \\
\text { N.D. } \\
\text { N.D. }\end{array}$ & $\begin{array}{l}60 \\
44 \\
29 \\
27\end{array}$ & $\begin{array}{l}\text { N.A. } \\
+ \\
+ \\
+\end{array}$ & $\begin{array}{l}+(N . A .) \\
+(D) \\
+(A)\end{array}$ & $\begin{array}{l}\text { N.D. } \\
\text { N.D. } \\
- \\
-\end{array}$ & duodenum fundic glandular polyps \\
\hline 8 & 299 & $\mathrm{ACT} \underline{\mathrm{CT}} \rightarrow \mathrm{ACTG}$ & $\begin{array}{l}14 \text { II:1 } \\
14 \text { II:2 } \\
14 \text { II:4 } \\
14 \text { III:3 } \\
14 \text { III:6 } \\
14 \text { III:7 }\end{array}$ & $\begin{array}{l}+ \\
+ \\
+ \\
+ \\
+ \\
+\end{array}$ & $\begin{array}{l}32 \\
31 \\
26 \\
14 \\
10 \\
12\end{array}$ & $\begin{array}{l}++ \\
++ \\
++ \\
+ \\
+ \\
\text { N.A. }\end{array}$ & $\begin{array}{l}+(C) \\
+(A)\end{array}$ & $\begin{array}{l}- \\
- \\
- \\
- \\
-\end{array}$ & $\begin{array}{l}\text { desmoid, fundic glandular polyps } \\
\text { desmoid } \\
\text { desmoid, fundic glandular polyps }\end{array}$ \\
\hline 9 & 332 & $\underline{\mathrm{C} G A} \rightarrow \underline{\mathrm{TGA}}$ & $\begin{array}{l}28 \text { I:1 } \\
28 \text { II:1 }\end{array}$ & $\begin{array}{l}\text { N.D. } \\
+\end{array}$ & $\begin{array}{l}66 \\
49\end{array}$ & $\begin{array}{l}<100 \\
<100\end{array}$ & $\begin{array}{l}+(C) \\
+(C)\end{array}$ & $\begin{array}{l}\text { N.D. } \\
-\end{array}$ & \\
\hline 11 & $470^{\mathrm{a}}$ & Exon 11 deletion & $\begin{array}{l}4 \text { II:1 } \\
4 \text { II:1 } \\
4 \text { II:3 } \\
4 \text { II:4 } \\
4 \text { II:6 } \\
4 \text { II:7 } \\
4 \text { II:8 } \\
4 \text { III:6 } \\
4 \text { III:7 } \\
4 \text { III:8 } \\
4 \text { III:9 } \\
4 \text { III:10 } \\
4 \text { III:12 } \\
4 \text { III:15 } \\
4 \text { III:16 } \\
4 \text { III:17 }\end{array}$ & $\begin{array}{l}\text { N.D. } \\
\text { N.D. } \\
\text { N.D. } \\
\text { N.D. } \\
\text { N.D. } \\
\text { N.D. } \\
\text { N.D. } \\
+ \\
\text { N.D. } \\
+ \\
\text { N.D. } \\
\text { N.D. } \\
+ \\
+ \\
\text { N.D. } \\
+\end{array}$ & $\begin{array}{l}39 \\
47 \\
36 \\
41 \\
34 \\
37 \\
29 \\
21 \\
20 \\
16 \\
21 \\
17 \\
20 \\
20 \\
17 \\
15\end{array}$ & $\begin{array}{l}\text { N.A. } \\
\text { N.A. } \\
\text { N.A. } \\
\text { m } \\
\text { N.A. } \\
+ \\
\text { N.A. } \\
\text { N.A. } \\
\text { N.A. } \\
++ \\
++ \\
\text { N.A. } \\
\text { m } \\
+ \\
\text { N.A. } \\
\text { N.A. }\end{array}$ & $\begin{array}{l}+(N . A .) \\
+(C) \\
+ \\
+(D) \\
+(D)\end{array}$ & $\begin{array}{l}\text { N.D. } \\
\text { N.D. } \\
\text { N.D. } \\
\text { N.D. } \\
\text { N.D. } \\
\text { N.D. } \\
\text { N.D. } \\
\text { N.D. } \\
\text { N.D. } \\
+ \\
+ \\
+ \\
+ \\
+ \\
+ \\
+\end{array}$ & $\begin{array}{l}\text { duodenum fundic glandular polyps } \\
\text { fundic glandular polyps } \\
\text { fundic glandular polyps } \\
\text { thyroid cancer }\end{array}$ \\
\hline 11 & $470^{a}$ & $\begin{array}{l}\text { ttaaattag/GGG } \rightarrow \\
\text { tttag/attagGGG } \\
\text { (ATTAG insertion) }\end{array}$ & $\begin{array}{l}5 \mathrm{l}: 1 \\
5 \mathrm{II}: 1 \\
5 \mathrm{II}: 2 \\
5 \mathrm{II}: 4\end{array}$ & $\begin{array}{l}+ \\
+ \\
+ \\
+\end{array}$ & $\begin{array}{l}49 \\
24 \\
23 \\
20\end{array}$ & $\begin{array}{l}+ \\
+ \\
\text { N.A. } \\
+\end{array}$ & $+(C)$ & $\begin{array}{l}+ \\
+ \\
+ \\
+\end{array}$ & $\begin{array}{l}\text { osteomas } \\
\text { left mandible osteomas }\end{array}$ \\
\hline 14 & $581^{a}$ & Exon 14 deletion & $\begin{array}{l}35 \text { I:1 } \\
35 \text { II:5 }\end{array}$ & $\begin{array}{l}\text { N.D. } \\
+\end{array}$ & $\begin{array}{l}50 \\
43\end{array}$ & $\begin{array}{l}\text { N.A. } \\
\mathrm{m}\end{array}$ & $\begin{array}{l}+(N . A .) \\
+(A)\end{array}$ & $\begin{array}{l}\text { N.D. } \\
\text { N.D. }\end{array}$ & \\
\hline 14 & 581 & $\begin{array}{l}\text { ctag/GAA } \rightarrow \text { ctgg/GAA } \\
\text { (exon } 14 \text { deletion) }\end{array}$ & $\begin{array}{l}11 \mathrm{I}: 1 \\
11 \|: 2 \\
11 \|: 4\end{array}$ & $\begin{array}{l}+ \\
+ \\
+\end{array}$ & $\begin{array}{l}47 \\
30 \\
22\end{array}$ & $\begin{array}{l}\text { N.A. } \\
+ \\
\mathrm{m}\end{array}$ & & $\begin{array}{l}+ \\
+ \\
+\end{array}$ & $\begin{array}{l}\text { stomach cancer } \\
\text { fundic glandular polyp }\end{array}$ \\
\hline 15 & $674^{\mathrm{a}}$ & $\begin{array}{l}\text { TTGACAATAGT } \\
\text { deletion }\end{array}$ & $\begin{array}{l}34 \text { II:3 } \\
34 \text { II:6 } \\
34 \text { III:1 }\end{array}$ & $\begin{array}{l}+ \\
+ \\
+\end{array}$ & $\begin{array}{l}35 \\
30 \\
16\end{array}$ & $\begin{array}{l}+ \\
+ \\
+\end{array}$ & $+(C)$ & $\begin{array}{l}\text { N.D. } \\
\text { N.D. } \\
\text { N.D. }\end{array}$ & sebacious cyst \\
\hline 15 & $831^{\mathrm{a}}$ & TTA $\rightarrow$ TTAE & $\begin{array}{l}44 \mathrm{I}: 1 \\
44 \mathrm{II}: 1\end{array}$ & $\begin{array}{l}\text { N.D. } \\
+\end{array}$ & $\begin{array}{l}31 \\
23\end{array}$ & $\begin{array}{l}\text { N.A. } \\
+\end{array}$ & $\begin{array}{l}+(D) \\
+(C)\end{array}$ & $\begin{array}{l}\text { N.D. } \\
\text { N.D. }\end{array}$ & \\
\hline 15 & 935 & $\mathrm{TA} \underline{\mathrm{C}} \rightarrow \mathrm{TA} \underline{\mathrm{A}}$ & $\begin{array}{l}13 \mid: 1 \\
13 \|: 1\end{array}$ & $\begin{array}{l}\text { N.D. } \\
+\end{array}$ & $\begin{array}{l}32 \\
29\end{array}$ & $\begin{array}{l}\text { N.A. } \\
+\end{array}$ & $\begin{array}{l}+(N . A .) \\
+\end{array}$ & $\begin{array}{l}\text { N.D. } \\
+\end{array}$ & thyroid, desmoid cancer \\
\hline 15 & $938^{\mathrm{a}}$ & ACTAAG $\rightarrow$ AG & $\begin{array}{l}7 \text { I:1 } \\
7 \text { II:1 } \\
7 \text { II:3 }\end{array}$ & $\begin{array}{l}\text { N.D. } \\
+ \\
+\end{array}$ & $\begin{array}{l}32 \\
23 \\
21\end{array}$ & $\begin{array}{l}+ \\
+ \\
+ \\
\text { N.A. }\end{array}$ & $+(C)$ & $\begin{array}{l}\text { N.D. } \\
\text { N.D. }\end{array}$ & \\
\hline 15 & 1309 & AAAGA deletion & 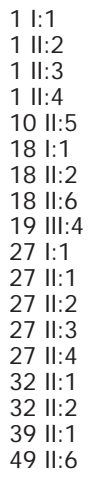 & $\begin{array}{l}\text { N.D. } \\
+ \\
+ \\
+ \\
+ \\
\text { N.D. } \\
\text { N.D. } \\
+ \\
+ \\
\text { N.D. } \\
\text { N.D. } \\
\text { N.D. } \\
+ \\
+ \\
\text { N.D. } \\
+ \\
+ \\
+\end{array}$ & $\begin{array}{l}34 \\
14 \\
17 \\
14 \\
30 \\
34 \\
28 \\
21 \\
25 \\
30 \\
19 \\
26 \\
23 \\
18 \\
30 \\
29 \\
21 \\
33\end{array}$ & $\begin{array}{l}+ \\
+ \\
+ \\
+ \\
+ \\
\text { N.A. } \\
\text { N.A. } \\
++ \\
++ \\
\text { N.A. } \\
++ \\
+ \\
+ \\
+ \\
\text { N.A. } \\
+ \\
\text { N.A. } \\
++\end{array}$ & $\begin{array}{l} \\
+(\text { N.A. }) \\
+ \text { (N.A.) } \\
+ \text { (D) } \\
+ \text { (C) } \\
+ \text { (N.A.) }\end{array}$ & $\begin{array}{l}\text { N.D. } \\
+ \\
+ \\
+ \\
+ \\
\text { N.D. } \\
\text { N.D. } \\
+ \\
+ \\
\text { N.D. } \\
+ \\
+ \\
\text { N.D. } \\
\text { N.D. } \\
\text { N.D. } \\
\text { N.D. } \\
\text { N.D. } \\
+\end{array}$ & $\begin{array}{l}\text { fundic glandular polyps, desmoid } \\
\text { fundic glandular polyps } \\
\text { fundic glandular polyps } \\
\text { epidermal cyst }\end{array}$ \\
\hline 15 & $1343^{\mathrm{a}}$ & $\mathrm{TC} \underline{\mathrm{T}} \rightarrow \mathrm{TT}$ & 33 ॥:4 & + & 33 & + & + & N.D. & \\
\hline 15 & $1428^{\mathrm{a}}$ & $\mathrm{GCA} \rightarrow \mathrm{GG}$ & $\begin{array}{l}16 \mid: 1 \\
16 \|: 2\end{array}$ & $\begin{array}{l}+ \\
+\end{array}$ & $\begin{array}{l}50 \\
21\end{array}$ & $\begin{array}{l}+ \\
+\end{array}$ & $+(\mathrm{C})$ & $\begin{array}{l}- \\
-\end{array}$ & \\
\hline 15 & $1503^{\mathrm{a}}$ & 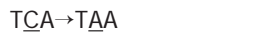 & $50 \|: 2$ & + & 17 & + & & N.D. & desmoid, fundic glandular polyps \\
\hline
\end{tabular}

${ }^{a}$ Novel mutation; polyps* $\mathrm{m}=$ multiple; $+=100-1000$ polyps; ++=more than 1000 polyps; cancer** $(\mathrm{X})$ Dukes stage; CHRPE ${ }^{\circledR}$; Congenital hypertrophy of the retinal pigment epithelium, - negative; + positive; N.A. Not available; N.D. Not done. 


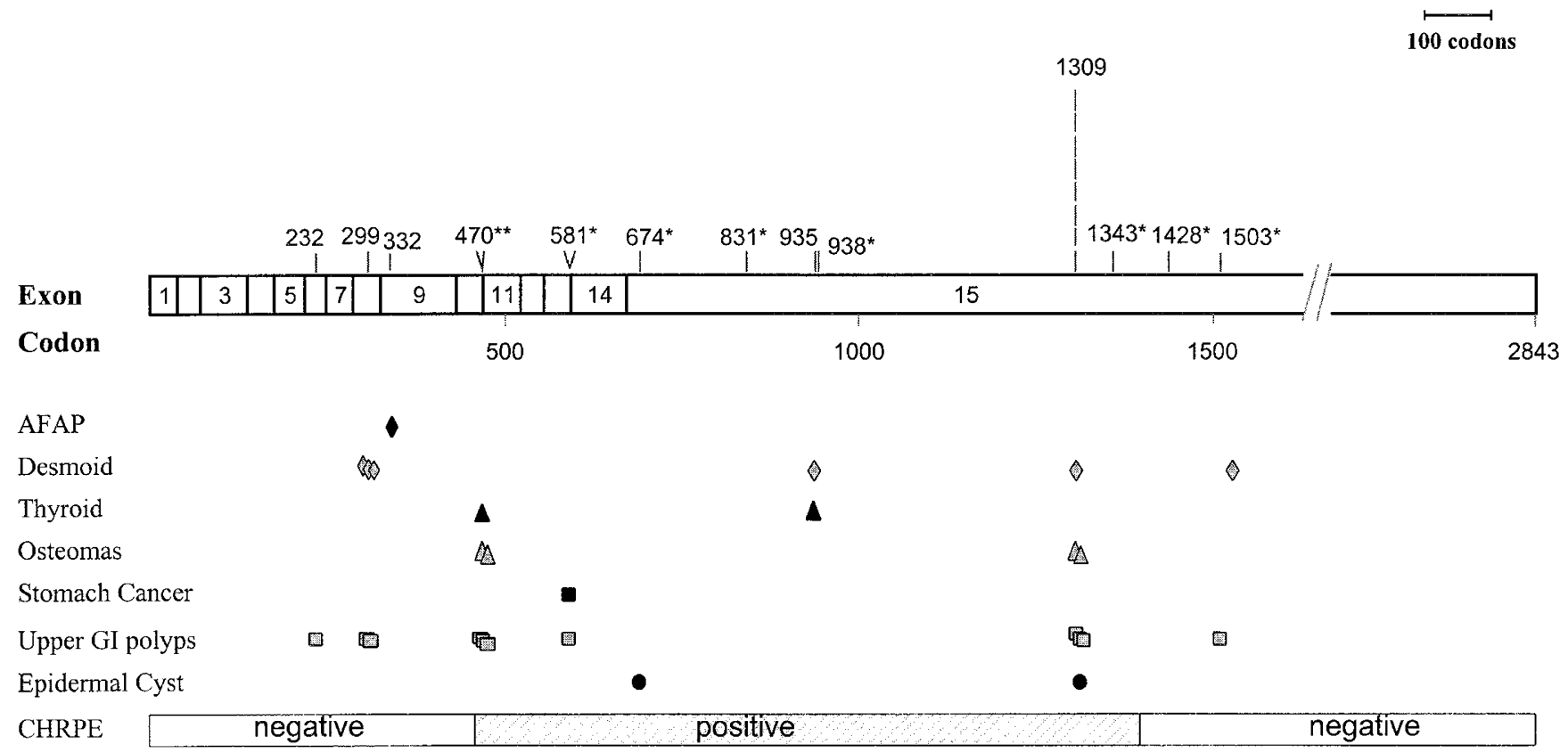

Figure 2 Distribution of APC germline mutations and phenotypic spectrum in 22 Singapore FAP families. The length of the bar indicates the number of mutations at the indicated position. Novel mutation is marked by an asterisk. Extracolonic manifestations associated with each mutation is indicated under the mutation site. Positive and negative CHRPE domains are indicated by the horizontal boxes.

introns (up to 40 bases) was found when the genomic DNA was sequenced. A similar finding was found in FAP family 35. cDNA sequencing indicates that exon 14 was deleted but no splice junction or neighbouring intron mutation was found. In some genes, exon skipping was found to be induced by the presence of intra-exon deletion in the genome, although the consensus sequences required for splicing were un affected. A recent study ${ }^{18}$ has found that deleted sequences within exon 19 of the dysotrophin gene functions as a cis-acting element for exact splicing of the upstream and downstream introns. We investigated whether this is true for the two families with deletions in exons 11 and 14 . We found no mutation in either exon suggesting that intra-exon deletion is not the reason for exon skipping in this case. We therefore speculate that these two mutations (del ex 11 and del ex 14) could be due to large genomic deletion involving these regions. The third mutation, at position 581, is caused by a substitution of the base adenine with guanine at position -2 in intron 13 resulting in the loss of the splice acceptor site and hence the deletion of exon 14.

Nonsensemutations Four different base-substitution mutations resulting in terminating codons were identified in four unrelated families (Table1). One of these four mutations (position 1503) is novel. It is caused by a substitution of the base cytosine with adenine at nucleotide4508, resulting in the conversion of the codon TCA to a terminating codon TAA. It is also the 3' most mutation for this study.

APC mutation spectrum Figure 2 summarises the APC mutation and phenotypic spectrum for the 22 Singapore FAP families. The most frequent mutation is the 5 base pair (AAAGA) del etion at codon 1309 which causes a frameshift in translation and termination occurs at codon 1313. This mutation is found in eight families, including three possible denovo mutations in FAP families 10, 19 and 49. Interestingly, these families are all of different ethnicity, comprising one Eurasian, one Chinese and one Malay family, respectively. The 1309 mutation is also the hot spot for APC germline mutation in the Western population (18\%). ${ }^{19}$ The frequency for Singapore FAP families (29\%) is considerably higher but is comparable with the $25 \%$ reported in the Japanese population. ${ }^{20}$ In contrast, we did not find any mutation in codon 1061, the second hot spot (12\%) for the Western population. ${ }^{19}$ The rest of the mutations are found in one family each, indicating that they are rare mutations, with the novel mutations possibly endemic to the local population.

\section{Genotype-phenotype correlation}

The phen otypic spectrum of these APC germline mutations is documented in Table1 and represented schematically in Figure2. 
All nine novel mutations have resulted in the loss of either one or both of the $\beta$-catenin binding sites which is crucial for APC to downregulate $\beta$-catenin and prevents the activation of the $\beta$-catenin/T cell transcription factor pathway. ${ }^{21}$ Patients with these germline mutations exhibit the classical FAP phenotype with more than 100 polyps in the colon (Table1).

As in Western studies, Singapore FAP patients with the 5 base pair deletion at codon 1309 have profuse polyps, and extracolonic manifestations such as osteomas, desmoid and CHRPE. Furthermore, the average age of onset of FAP patients with mutation at this position (26years) is 14years earlier than patients with mutation at other sites (39years). Six of the eight patients with mutation at codon 1309 eventually die of cancer before age 35. In the case of FAP 49 II:6, there are more than 5000 polyps in his colon.

The mutations with CHRPE manifestation, wherever it is determined, are at positions470, 581, 935 and 1309. The mutations where no CHRPE manifestations are at 299, 332 and 1428, respectively (Table1 and Figure 2 ). This demarcation appears to be consistent with the findings of an earlier study ${ }^{10}$ delineating the CHRPE limits to the region between codons 463 and 1387.

In addition, the characteristics of other extracolonic manifestations such as desmoid and thyroid carcinomas are similar to those in Western FAP families. In six out of seven Singapore FAP patients, desmoid manifested a few years after surgery. Thus, it is possible that the occurrence of desmoid tumours in these patients is associated with surgical trauma as reported in earlier studies. ${ }^{22}$ All three cases of FAPassociated thyroid cancers in this study are papillary carcinomas. The patients are young females (average age is 20 years) and thyroid carcinoma was diagnosed before FAP. Furthermore, all three patients have retinal lesions. These features are similar to those affected patients from the West. ${ }^{23}$ However, unlike the Western FAP patients, two out of three patients in the present study al so have desmoid tumours (FAP $6 \mathrm{Il}: 3$ and $13 \mathrm{Il}: 1)$. We found only one case of stomach cancer (FAP $11 \mathrm{I}: 1$ ) and no case of FAP-associated brain tumour or hepatoblastoma in accordance with the rarity of these manifestations. ${ }^{24,25}$

In this study, we found new positions associated with desmoid (299 and 935), thyroid cancer (470 and 935), and stomach cancer (581) which have not been previously reported. Another interesting point to note is that contrary to the reported right-sided dominance of polyps for attenuated FAP (AFAP), ${ }^{9}$ the patients at mutation 332 in the present study manifested with more polyps on the left rather than the right side of the colon. Both mother and son had sigmoid cancers. This indicates that right-sided predominance is not an absolute requisite for AFAP.

CHRPE is the only phenotype with no intra-family variation. The full correspondence of CHRPE with the mutation domain would enable clinicians to predict affected members and provide a useful lead for genetic testing. In contrast, although 16 members of FAP family 4 are patients, FAP 4 III:17 is the only member with thyroid carcinoma, indicating the large intra-family variability (Table1). It is as yet unclear why CHRPE is the only phenotype that is not influenced by varying modifying genes and/or environmental (dietary) factors.

\section{FAP families without detectable APC germline mutation}

Although more than $98 \%$ of APC mutations are truncating, ${ }^{5}$ it is possible that the six FAP families without detectable APC mutation have non-truncating mutations that are not detected by PTT. Alternatively, some of these families could have disease-causing germline mutations in genes other than the APC.

In an earlier report, we showed that $\beta$-catenin germline mutation was not found in these six families, suggesting that they may have germline mutation in other genes that are involved possibly in an APC-independent pathway. ${ }^{15}$

Moreover, phenotypic analysis revealed that three of these families have atypical FAP features. Patients from these families have mixture of adenomatous and hyperplastic polyps. Except for one individual, the number of polyps in all these patients ranged from a few to about 50. Furthermore, there was no documentation of extracolonic manifestation in these families. These features are suggestive of a different syndrome. The other three families exhibit classic FAP features.

In conclusion, we have identified APC germline mutation in 22 out of 28 Singapore FAP kindreds. We demonstrated that PTT is a highly reliable, relatively non-invasive and presymptomatic tool for FAP screening. DNA sequencing analyses revealed that nine out of 15 different mutations are novel, indicating that the mutational spectrum of APC is highly heterogeneous. Similar to Western studies, the (AAAGA) deletion at codon 1309 is the hot spot for germline mutation in the Singapore FAP families. However, we did not find any mutation at codon 1061, the second hot spot for the Western kindreds. With the exception of CHRPE, differences in occurrence and frequency of colonic and extracolonic manifestations within the FAP kindreds suggest the influence of modifying genes and environment factors.

\section{Electronic database information}

The eight novel mutations have been submitted to the Human Gene Mutation Database (HGMD), http://link.springer.de/journals/humangen/mutation/.

\section{Acknowledgements}

The authors would like to thank Ms Jocel yn Yao from the laboratory for help with RT-PCR, and Ms Carol Loi and Koh Yin Fung from the Singapore Polyposis Registry for help in retrieving the pedigrees and clinical data. This work is funded in part by a grant from the National Medical Research Council (NMRC/0239/1997) of Singapore. 


\section{References}

1 Kinzler KW, Vogelstein B: Lessons from hereditary colorectal cancer. Cell 1996; 87: 159-170.

2 Groden J, Thliveris A, Samowitz W et al: Identification and characterization of the familial adenomatous polyposis coli gene. Cell 1991; 66: 589-600.

3 Joslyn G, Carlson N, Thliveris A et al: Identification of deletion mutations and three new genes at the familial polyposis locus. Cell 1991; 66: 600-613.

4 Kinzler KW, Nilbert MC, Su LK et al: Identification of FAP locus genes from chromosome5q21. Science 1991; 253: 661-665.

5 Beroud C, Soussi T: APC gene: database of germline and somatic mutations in human tumors and cell lines. Nucleic Acids Res 1996; 24: 121-124.

6 Nagase $\mathrm{H}$, Nakamura Y: Mutations of the APC (adenomatous polyposis coli) gene. Hum Mutat 1993; 2:425-434.

7 Spirio L, Olschwang S, Groden J et al: Alleles of the APC gene: an attenuated form of familial polyposis. Cell 1993; 75: 951-957.

8 Friedl W, Meuschel S, Caspari R et al: Attenuated familial adenomatous polyposis due to a mutation in the $3^{\prime}$ part of the APC gene. A clue for understanding the function of the APC protein. Hum Genet 1996; 97: 579-584.

9 Soravia C, Berk T, Madlensky L et al: Genotype-phenotype correlations in Attenuated adenomatous polyposis coli. Am J Hum Genet 1998; 62: 1290-1301.

10 Olswang S, Tiret A, Laurent-Purg P, Muleris M, Parc R, Thomas G: Restriction of occular fundus lesions to a specific subgroup of APC mutations in Adenomatous Polyposis Coli patients. Cell 1993; 75: 959-968.

11 Davies DR, Armstrong JG, Thakker $\mathrm{N}$ et al: Severe Gardner Syndrome in families with mutations restricted to a specific region of the APC gene. Am J Hum Genet 1995; 57: 1151-1158.

12 Roest PAM, Roberts RG, Sugino S, van Ommen GB, den Dunnen JT: Protein truncation test (PTT) for rapid detection of translationterminating mutations. Hum Mol Genet 1993; 2: 1719-1721.

13 Powel SM, Peterson GM, Krush AJ et al: Molecular diagnosis of familial adenomatous polyposis. New Engl J Med 1993; 329: 1982-1987.

14 Miller SA, Dykes DD, Polesky HF: A simple salting out procedure for extracting DNA from human nucleated cells. Nucleic Acids Res 1988; 16: 739.
15 Cao X, Eu KW, Seow CF, Cheah PY: Germline mutations are frequent in the APC gene but absent in $\beta$-catenin gene in Familial Adenomatous Polyposis patients. Genes Chromosomes Cancer 1999; 25: 396-398.

16 Miyoshi $\mathrm{Y}$, Ando $\mathrm{H}$, Nagase $\mathrm{H}$ et al: Germline mutations of the APC gene in 53 familial adenomatous polyposis patients. Proc $\mathrm{N}$ atl Acad Sci USA 1992; 82: 4452-4456.

17 van der Luijt RB, Khan PM, Vasen HFA et al: Molecular analysis of the APC gene in 105 Dutch kindreds with Familial Adenomatous Polyposis: 67 germline mutations identified by DGGE, PTT and Southern analysis. Hum Mutat 1997; 9: 7-16.

18 Pramono ZA, Takeshima Y, Alimsardjono H, Ishii A, Takeda S, Matsuo $\mathrm{M}$ : Induction of exon skipping of the dystrophin transcript in lymphoblastoid cells by transfecting an antisense oligodeoxynucleotide complementary to an exon recognition sequence. Biochem Biophys Res Commun 1996; 226: 445-449.

19 Laurent-Puig, Beroud C, Soussi T: APC gene: database of germline and somatic mutations in human tumors and cell lines. Nucleic Acids Res 1998; 26: 270-273.

20 Miyaki M, Konishi M, Kikuchi-Yanoshita R et al: Characteristics of somatic mutation of the Adenomatous Polyposis Coli gene in colorectal tumors. Cancer Res 1994; 54: 3011-3020.

21 Rubinfeld B, Albert I, Porfiri E, Fiol C, Munemitsu S, Polakis P: Binding of GSK-3 $\beta$ to the APC- $\beta$-catenin complex and regulation of complex assembly. Science 1996; 272: 1023-1026.

22 Lynch HT, Fitzgibbons R Jr: Surgery, desmoid tumors, and familial adenomatous polyposis: case report and literature review. Am J Gastroenterol 1996; 91: 2598-2601

23 Cetta F, Olschwang S, Petracci M et al: Genetic alterations in thyroid carcinoma associated with familial adenomatous polyposis: clinical implications and suggestions for early detection. World J Surg 1998; 22: 1231-1236.

24 Wallace $\mathrm{MH}$, Phillips RK: Upper gastrointestinal disease in patients with familial adenomatous polyposis. Br J Surg 1998; 85: 742-750.

25 Hamilton SR, Liu B, Parsons R et al: The molecular basis of Turcot's syndrome. N Engl J Med 1995; 332: 839-847. 